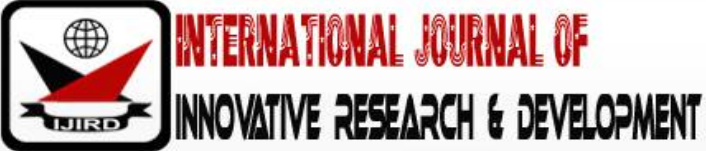

ISSN 2278 - 0211 (Online)

\section{Cattle Rustling and Banditry: Impact on Education Enrolment \& Completion in Zammfara State, Nigeria}

\begin{tabular}{|c|}
\hline Dr. Shehu Suleiman Abdullahi \\
Lecturer, Department of Educational Foundations, \\
Federal University Gusau, Zamfara State, Nigeria \\
Binta Muhammed \\
Lecturer, Department of Educational Foundations, \\
Federal University Gusau, Zamfara State, Nigeria \\
Victor E \\
Lecturer, Department of Educational Foundations, \\
Federal University Gusau, Zamfara State, Nigeria
\end{tabular}

\begin{abstract}
:
In recent time, cattle rustling and banditry has been a veritable threat to public safety and security in north-westNigeria, Zamfara State inclusive. In this state, the activity has led to closure of schools and learner's displacement, loss of lives, human injury, population displacements, as well as loss of cattle in their numbers. This scenario goes with repercussions that do not portend well for the collective wellbeing of farmers and herding communities. It was in line with this development that, this paper examined Brief history and genesis of cattle rustling and banditry in Zamfara state which was found to be associated with the recent developments which tend to have implicated cattle rustling in the rising wave of violence in northern Nigeria, as exemplified in the phenomenon of Boko Haram insurgency and herder/farmer conflicts. In the same vein, the paper identified causes of cattle rustling, which include lack of sensitization of people to apply land use act of 1978; Claim for scarce resources ownership position of land; Lack of grazing reserves and delineated stock routes for Fulani herdsmen; Furthermore, some specific impacts were enumerated and these were: killing of hundreds of innocent people of Zamfara (Male, Female, Boys and Girls) over the years; Impacted negatively on the mining and solid minerals opportunities in the state; Additionally, the paper highlighted effort put in place to curtailed the activities as thus: Released all cows and sheep's in the possession of herders to state governments; State Governor gave additional 47 Hilux for security \& surveillance patrol in 14 local governments.; A quick response tack- force of security personal were deployed at strategic place; Re-conciliation committee was constituted to check the activity: Commissioner of police conducted tour and sensitized populace on the implication of taking laws in ones hand. Lastly, conclusion and recommendations were made
\end{abstract}

Keywords: Cattle rustling, banditry, fulani herdsmen, education, enrolment, completion

\section{Introduction}

In Northwest, Nigeria, the prevalence of cattle rustling has been widespread, where cattle raring obtain as a dominant agricultural practice. Recent developments tend to have implicated cattle rustling in the rising wave of violence in northern Nigeria, as exemplified in the phenomenon of Boko Haram insurgency and herder/farmer conflicts This scenario has accentuated the significance of cattle rustling as a fundamental national security problematic in Nigeria. Consequentially, this would have adverse effect on lives and properties of the affected communities in the northwest states and in turn led to displacement of people and killing \& stolen of cows in large number. (Daily Trust 2014 February; Okoli and Iortyer, 2014; (Okoli and Atelhe, 2014.)

The recent classification of some Fulani herdsmen as Boko Haram collaborators by the Nigerian military and politicians reveals the complexities of violent clashes between cattle breeders and sedentary agriculturalists across different parts of the country. The alleged involvement of camel pastoralists from the Republic of Niger in some conflicts in the north-western and central regions of Nigeria also highlights the need to investigate the multidimensional causes and the politicization of a problem that spills over to neighboring countries. For instance, analyses the relationship between herdsmen and farmers as an economic exchange of dairy products for grain, access to local markets, and the provision of manure on arable land while the cattle consume crop residues. Olaniyan, \& Aliyu 2016; Okoli and Atelhe, 2014; Okoli and Iortyer, 2014).),

However, the claims that, religious and cultural factors, are key to peaceful relationships that became less cordial as the Fulani migrated further south. This has led to several agitations in the past, notably by the Miyetti Allah Cattle Breeders Association of Nigeria (MACBAN), which advocates for the social, political, economic, and cultural integration of 
Fulani in communities where they settle (Awogbade 1987). Climate changes, the migration further south, the growth of agro-pastoralist, the expansion of farming on pastures, the invasion of farmlands by cattle, assault on non-Fulani women by herders, blockage of stock routes and water points, freshwater scarcity, burning of rangelands, cattle theft, inadequate animal health care and disease control, overgrazing on fallow lands, defecation on streams and roads by cattle, extensive sedentarisation, ineffective coping strategies, ethnic stereotyping, and the breakdown of conflict intervention mechanisms-these are usually identified by scholars as the root causes of such violence in rural areas (Folami 2009; Ofuoku and Isife 2009; Adekunle and Adisa 2010; Blench 2010; Odoh and Chigozie 2012; Solagberu 2012; Audu 2013; McGregor 2014).

In line with this, Abass (2012) contends that the major source of tensions between pastoralists and farmers is basically economic, with land related issues accounting for the majority of the conflicts. This can then be situated within the broader context of the political economy of land struggle, traceable to a burgeoning demography in which there is fierce competition for fixed space to meet the demands of the growing population (Olabode and Ajibade 2010; Solagberu 2012). However, it has been observed that ecological and economic determinism may not capture the complexities embedded in the conflict contexts of these groups. And also, contextual analyses of 'local socio-ecological conditions' and diversity of pastoral populations in accounting for their nutritional habits (Blench,2010)

Therefore, there is need to overcome the socio-cultural stereotyping of nomadic life and relate experiences to their contexts, while taking cognizance of the holistic functioning systems of local economies. In more recent times, transhumant herdsmen coexist with agro-pastoralists and farmers who have also taken to cattle breeding and this has redefined their perceptions of and relationships with each other, hence, cattle rustling and banditry activities in the affected communities has led to loss of lives, human injury, population displacements, as well as loss of cattle in their numbers. This situation goes with repercussions that do not portend well for the collective wellbeing of the herding communities. It creates a sense of insecurity which has the capacity to hamper the productivity of the herding enterprise. The loss of cattle to rustlers means depletion of household income and communal resource of the herding community. (Blench 2010; Krause 2011; Abass 2012; Audu 2013; McGregor 2014)

The implications of this for sustainable productivity of the herding venture are easy to decipher and this could ultimately lead to drop in the aggregate supply of organic protein and dairy in Nigeria. What is more critical and dicier is the correlation between cattle rustling and spiral violence in some parts of northern Nigeria. The incessant attacks by cattle rustlers on herding communities tend to set them at loggerheads with their ecological neighbours. (Olaniyan, \& Aliyu 2016), In some instances, the farmers are arbitrarily accused by the herders as the culprit and masterminds of their cattle raids. This engenders ill feelings that exacerbate the already conflictive herder/farmer inter-group relations, leading ultimately to vicious circle of violence. Another critical dimension of the implication of cattle rustling is its apparent degeneration into a terror-brand mass raids wherein innocent villagers, including women and children are victimized are often killed. Only recently, the public sensibilities of Nigerians were outraged over the report of massive killings and raping that characterized one of the recent occurrences of cattle rustling escapade in Katsina and Kaduna states in February, (2014), If this development is a necessary trajectory of cattle rustling in its dynamics of degeneration, the implication is that it passes for terrorism in terms of destructive import. (Olaniyan, \& Aliyu 2016),

\section{Nature and Courses of Cattle Rustling and Banditry in Zamfara State}

Zamfara State is a state located in North- Western Nigeria. Its capital is Gusau. Until 1996 the area was part of Sokoto State. Although the people of Zamfara have over the years struggled to have autonomy, it was not until 1996 that the then Military Administration of the Late General Sani Abacha detached Zamfara State from the former Sokoto State. Zamfara is largely inhabited by Hausa and Fulani tribes. Other major tribes include the Zamfarawa mainly from Anka, Gummi, Bukkuyum and Talata Mafara Local Governments areas. Gobirawa from Shinkafi Local Government. Gobirawa are those who actually migrated from the Gobir Kingdom. Burmawa are found in Bakura and Fulani are found in Bungudu, Maradun, Gusau and are also scattered all over the State. While in Tsafe, Bungudu and Maru Local Governments are found Katsinawa, Garewawa and Hadejawa. While Alibawa are found in Kaura Namoda and Zurmi. (Olaniyan, \& Aliyu 2016), Zamfara state has an area of 39,762 square kilometers. It has a population of 3,602,356 according to the 1991 census and contains fourteen local government areas. The state is bordered in the North by Niger republic, to the South by Kaduna State. In the east it is bordered by Katsina State and to the West by Sokoto and Niger States. Agriculture is the most predominant and important occupation of the people of the state, hence its slogan "farming is our pride". (Olaniyan, \& Aliyu 2016),

In the recent time when other part of the northern country are battling with their own peculiar security challenges such as insurgency and other forms of militia attacks, the problems associated with cattle rustling and its aftermath continue to raised serious suspicion among the people of Zamfara on how the phenomenon metamorphosed to bloody circumstances that costs over one thousand lives in less than two years. From Linyado to Guru attacks, killings of over fifty people in Kizara community, attack on Dansadau, Dangulbi, Rukudawa, and several other communities in Tsafe, Zurmi and Dan-sadau Emirate councils, residents of Zamfara continue to entertain fear as to whether if these daily attacks will not consume both the economic and social development of the state in the long run. (Olaniyan, \& Aliyu 2016),

Since 2011 when the conflict reached an advance stage, security measures have been put in place to contain the security challenges and to a large extent federal government intimated the police force headquarters and other sister security agencies to support the state in the fight against these hoodlums "suspected cattle rustlers" all in vain, the intervention yielded little or no result because it is either the cause root of the matter is not known or the real people who are the key actors are not fully and adequately contacted. However, in Zamfara state, the following are attributed to be the root causes of cattle rustling: (Olaniyan, \& Aliyu 2016), 
- Lack of grazing reserves and delineated stock routes for Fulani herdsmen

- Decline in internal discipline and socio-cohesion

- Poor surveillance and in-effective security network in the state to curb crime activities from inception

- Access right to farm land and cattle routes (labi)

- Ignorant about land tenure Act of 1978 (land ownership)

- Complex land use system that has changed markedly over-time

- Difference in ethnic, cultural values \& norms of the Fulani and the farmers

\section{Impact on Educational Enrolment and Completion of School Age Pupils}

Before the advent of cattle rustling and banditry in the state, already the state is faced and battling with problem of out of school children, which is seen as a great challenge to socio-economic development of the state. With advent of cattle rustling activities it further worsening the situation, were by existing schools in the vulnerable communities were the attack is incessant lead to closure of schools, displacement of children and their parents and of course converting schools to IDP camp. It was on this background one can now see that rustling and banditry have negative consequential impacts on educational provisions which is so glaring on daily reports made available through printed media, paper presentations and articles. The bellow table of result analysis shade lighter as thus:

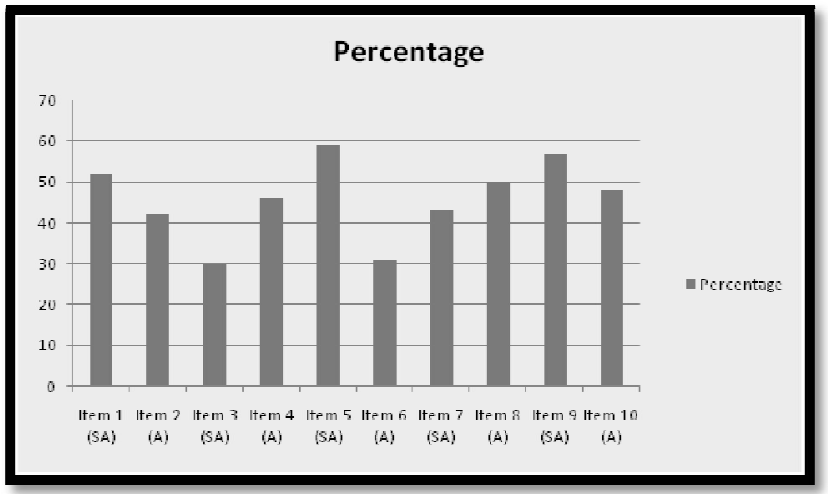

Figure 1: Impact of Cattle Rustling and Banditry on Children Education \& Its Socio-Economic Impact

Result analysis on activity of cattle rustling and banditry on children education and socio-economic impacts was responded to and the analyzed results in the bar-chart indicated that: 155 frequency responses to strongly agree which representing (52\%) percentage, revealed activities of cattle rustlers denied age-bracket children to attend school in the affected community. While, 127 respondents representing (42\%), of Agreed revealed that some of the enrolled children have abandoned schooling given the reason to converting their schools to IDP or criminal hideout. 121 respondents representing $60 \%$ percent of the school children were displaced to another community. Respondents on the effect revealed stolen cows, mis-placed and killed ones of 178 frequency, which represented (59\%) percentage. Furthermore, 89 frequency account $(29 \%)$ of strongly agree respondents indicated that socio-economics activities in the affected community has deteriorated. 129 representing (43\%), percentage that of enrolment and completion of schooling by the children has been affected. While, 157 that represented (50\%) of agree respondents to rustling activities is a threat to safety and security of the community. The activity leads to forcefully closure of some schools in the affected communities

\section{Socio-Economic Impact and Development of Zamfara State}

Zamfara states populace has suffered devastating effects of the activities of cattle rustling and banditry in the targeted communities and the state at large and these include the following:

- Killing of hundreds of innocent people of Zamfara over the years under review, no one can estimate the high rate of economic lost encountered by the people of the state especially food and other livestock either destroyed or stolen from the affected areas. The police Commissioner Ahmed Ibrahim at a briefing to mark his seventy days in office informed journalists that, within his days over two thousand stolen cattle have been recovered by the police while over one hundred suspected cattle rustlers have been arrested while some are under prosecution.

- As one of the bad aspects of these deadly attacks, is that in every single attack, there must be lost of live and properties while severally houses and places of worships are been the target of these hoodlums which led to the crippled investment opportunity of the state because foreign investors due to lack of safety of their life and property.

- A clear example was the threat on some of the official of road construction companies along the Dansadu area who were ask to quit their location of work or be killed.

- Similarly, the development has impacted negatively on the mining and solid minerals opportunities henceforth the foreign companies and investors did no longer considered Bagegga and mining communities safer for economic attraction. 
- Movement of goods and other agricultural product is no longer possible considering the fact people and even the security agencies are been attacked on the daily basis while farmlands are equally destroyed even before harvest and the hope for agricultural is almost dashed out.

- Above all the exit of the Fulani people from Zamfara state due to the increasing rates of attack against their settlements and other livestock remain one of the most critical economic challenges heating the state.

- Recent studies revealed that Fulani contributes up to eighteen percent of the state GDP and contributes about twenty four percent of the state IGR but with the situation on ground trailers loaded with Fulani people and their luggage's are been sighted almost on daily basis living the state for lack of safety.

- When you visit some of the Fulani settlements along Dan-sadau forest, majority of schools for nomadic education constructed for these people were abandoned because their children are no longer interested in the western education rather than to leave for a safer place out of Zamfara.

\section{Suggested Conflict Resolution Mechanism to Cattle Rustling in Zamfara State}

The state government as part of her resolution of conflict between Fulani herdsmen and farmer dialogued with them and agreed to laid down arms in their possession. In the process, the notorious gang leader promised to ensure no rustling activities in the state anymore. The leader known as Bukharin Daji was made Special adviser SA forestation. His key lieutenant, agreed to join the state task-force established to fight against criminal activities throughout the state

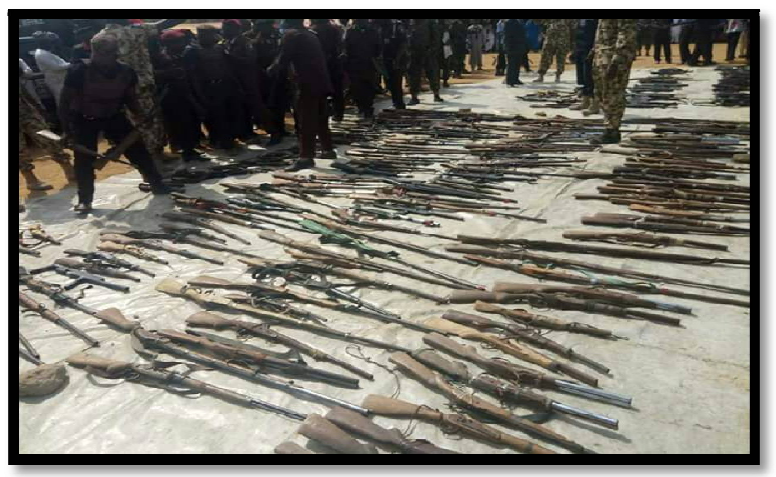

Figure 2: Arms Recovered from Bandit

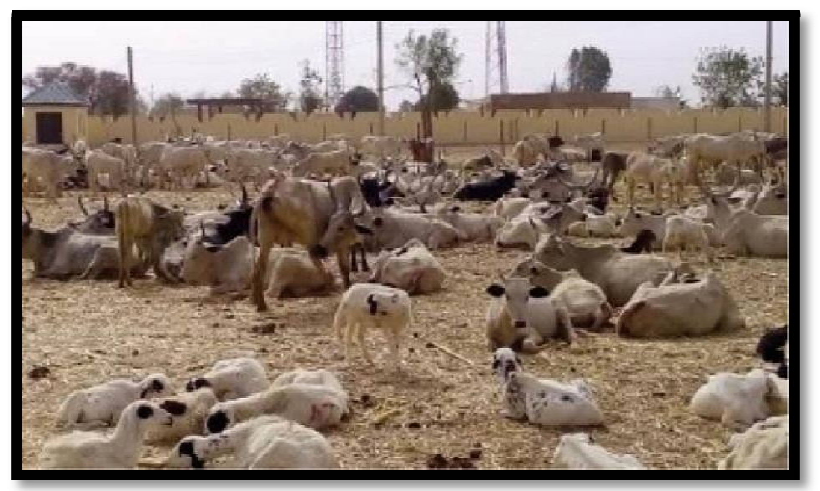

Figure 3: Recovered Animals from Fulani Herders

Therefore, the inaugurated reconciliation committee headed by the deputy governor the person of "Alh. Ibrahim Wakkala Muhammad Sarkin Malamai, in order to put a stopped to the activities of cattle rustling the following specific measures are taking:

- The present Commissioner of Police in the state CP Ahmed Ibrahim opted to applying "stick and carrot" approach in resolving the lingering crises and it is already yielding positive result.

- Made Bukharin daji the head of herdsmen special adviser of afforestation in Zamfara;

- Released all cow's sheep's in the possession of herders to state governments;

- The governor gave additional 47 Hilux for security \& surveillance patrol in 14 local governments.;

- In Zamfara state a quick response tack- force of security personal was deployed at strategic place;

- Through the re-conciliation committee the two parties have voicing out their minds on issues of conflicting interest and the state government had proffer measures to dis-agreement resolution.

- CP's conducted tour and sensitized populace on the implication of taking laws in to their hand and the need for the security agencies and those in the position of authorities to be more open in their dealings.

\section{Conclusion \& Recommendations}

Cattle rustling and banditry activities in Zamfara state became widespread to other local governments as a result of Luke-warm attitude of the state government right from inception to take pro-active measures and intercept, but rather it was politicized and not until when the perpetrators wax stronger and extending their raiding activities to cover more 
local governments and communities that little effort was put in place to combat the ordeal. However, with realizing and degenerating effect that the cattle rustling coursed in relation to loss of lives and properties and killing thousands of people and stolen of thousand of cows compelled the state to take some actions in order to put a stoppage to the nefarious activities, though seems late but the measures as achieved some good results but more needs to be done

\section{Recommendations}

The following recommendations were made in order to maintained and improve on the success reach in putting a stop to cattle rustling activities in the state:

- The re-conciliation committee should ensure resolutions reached are followed and maintained for peaceful coexistence between Fulani herders and farmers

- The joint task force formed for surveillance should ensure prompt action to any up-rising or violence

- State government should ensure justice and fairness in distributions of the cows and sheep collected from herders

- The promised grazing reserve and route stock for Fulani cow grazing should be a reality

- The quarterly Fulani stakeholders meeting to sensitize farmers, Fulani herders and entire populace on the land tenure act of 1978

\section{Acknowledgement}

The authors of this research work do acknowledge Tertiary Education Trust Fund (Tetfund)-Abuja- Nigeria, for sponsoring the conduct of this research work to its logical conclusion. Similarly, worthy to mention at this level is office of the Director of research Federal University-Gusau, Zamfara State, for facilitating and coordinating the process and product in completing the study.

\section{References}

i. Bukar Mada • Posted in TASKAR ZAMFARA • Tagged History of Zamfara, Zamfara State

ii. Daily Trust (2014 February). Arresting the menace of cattle rustling. Editorial, February 05, 2014, p...

iii. Daily Trust (2014 February). Investigation: 322 herders killed; 60,000 cattle rustled in 2013. Daily Trust online at http://dailytrust.info/likked-60,000-cattle-rustled-in-2013 (accessed March 20, 2014).

iv. Microsoft Student Encarta (2008 DVD). Cattle rustling. Redmond, WA: Microsoft Corporation.

v. Mohammed B., T., C, (2013) PERSPECTIVES ON THE CONFLICT BETWEEN FARMERS AND TRANSHUMANTS PASTORALISTS IN NIGERIA. Secretary General of Confederation of Traditional Herder Organizations in Africa (CORET) Suites 507/508, 5th Floor, Bank of Industry Building, 18 MuhammaduBuhari way, Kaduna-Nigeria, secgencoret@gmail.com coret_africa@yahoo.com (accessed March 25,2014).

vi. Okello et al. (2014). Identifying Motivators for State-Pastoralist Dialogue: Exploring the Relationships between Livestock Services, Self-Organisation and Conflict in Nigeria's Pastoralist Fulani. Pastoralism: Research, Policy and Practice. Vol 4, No. 12. pp 1-14

vii. Olabode, A. and Ajibade, L. (2010). Environment Induced Conflict and Sustainable Development: A Case of Fulani-Farmers' Conflict in Oke-Ero LGAS, Kwara State, Nigeria. Journal of Sustainable Development in Africa. Vol. 12, No.5. pp 259-273

viii. Okoli, A. \& Okpaleke, F. N. (2014). Cattle Rustling and Dialectics of Security in Northern Nigeria. International Journal of Liberal Arts and Social Science Vol. 2 No. 3 April, (2014) Department of Political Science, Federal University Lafia, PMB 146, Lafia, Nasarawa State, Nigeria Email:

ix. Okoli, A.C and Agada, A.T. (2014). Kidnapping and national security in Nigeria. Research on Humanities and Social science, 4(6), pp 137-146.

x. Okoli, A.C and Atelhe, G.A (2014). Nomads against Natives: A political ecology of herder/farmer conflicts in Nasarawa State, Nigeria. American International Journal of Contemporary Research, (2), pp.76-88.

xi. Okoli, A.C and Okpaleke, F (2014). Banditry and Crisis of public safety in Nigeria: Issues in national security strategies. European Scientific Journal, 10(4), pp.350-362. International Journal of Liberal Arts and Social Science Vol. 2 No. 3 April, 2014117

xii. $\quad$ Okoli, A.C. (2014a). Disaster management and national security in Nigeria. International Journal of Liberal Arts and Social Science, Vol. 2(1) pp. 21-59.

xiii. Okoli, A.C. (2014b). Commercialism and commodification of illicitly: A political economy of baby buying/selling in South East of Nigeria. International Journal of Liberal Arts and Social Science, 2(2). pp. 77-85.

xiv. Okoli, A. \& Okpaleke, F. N. (2014). Cattle Rustling and Dialectics of Security in Northern Nigeria. International Journal of Liberal Arts and Social Science Vol. 2 No. 3 April, (2014) Department of Political Science, Federal University Lafia, PMB 146, Lafia, Nasarawa State, Nigeria Email: okochu007@yahoo.com, okpalekefrancis@gmail.com

xv. Olaniyan, Azeez / Yahaya, Aliyu (2016), Cows, Bandits, and Violent Conflicts: Understanding Cattle Rustling in Northern Nigeria, in: Africa Spectrum, 51, 3, 93-105. URN:

http://nbn-resolving.org/urn/resolver.pl?urn:nbn:de:gbv:18-4-9894 ISSN: 1868-6869 (online), ISSN: 00020397

xvi. The Genesis of Zamfara Cattle Rustling and Quest for Community Dialogue 